\title{
Libanon: Mordet, der ikke ville gå væk
}

Lasse Ellegaard

\section{De fleste har principielt ingen indvendinger mod en opklaring af, hvem der stod bag attentatet mod Rafik Hariri i 2005, men de er nervøse for konse- kvenserne}

Ernest spørger: "Hvad nytter det? Hariri har været død i mere end fem år. At anklage nogen for mordet vil kun koste mere blod. Lad Hariri hvile i fred - det er bedst for stabiliteten."

Ernest - hans far læste Hemingway - er arabisk journalist, ansat på en avis i Beirut. Hans tilsyneladende kynisme i relation til lov og ret er ikke produkt af hans temperament, men af situationen. Og den kan spores hos diplomater, journalister og hos mange libanesere, for hvem sandheden om mordet under alle omstændigheder vil være ilde hørt.

Ræsonnementet: Hariri er død, men Libanon skal videre, er et tilbagevendende argument i debatten om mordet på den 60-årige libanesiske sunnileder og 22 andre i 2005.

Men videre fra hvad?

Mordet medførte et politisk skifte.
Gigantiske protestdemonstrationer mod Syrien i ugerne efter mordet kombineret med et amerikansk pres på den syriske ledelse - amerikanerne stod allerede i Irak - fik præsident Bashar al-Assad til at trække sine syriske tropper tilbage efter 29 års de facto besættelse af det lille naboland. Den Syrien-venlige - og følgelig Israel-fjendtlige - regering, der havde samarbejdet - eller var dirigeret - af syriske sikkerhedstjenester, gik af, og et valg resulterede i en vestligt orienteret regering, ledet af Hariri-klanens bogholder, Faoud Siniora.

$\mathrm{Nu}$, fem år efter, er Syrien tilbage med ikke kun en ambassade, men igen som den mest indflydelsesrige politiske faktor i libanesisk indenrigspolitik. Et forløb tegner sig: Mordet på Hariri i 2005 førte til de 33 dages krig med Israel i 2006, provo- 
keret af den shia-muslimske Hizbollah-milits netop som den stod over for krav om afvæbning. Krigen resulterede i politisk lammelse af Libanon frem til 2008, hvor en samlingsregering blev dikteret af Syrien-Saudi-Arabien-Iran-USA, hvor Hizbollah og allierede Syrien-venlige partier har vetoret. Denne regering har været lammet siden begyndelsen af november som følge af en forventet rapport fra den særlige FN-kommission, der efterforsker mordet på Hariri, og som forventes at udpege Hizbollah som ansvarlig.

\section{Bekymring for opklaring}

De fleste har principielt ikke indvendinger mod en opklaring af, hvem der stod bag attentatet mod milliardær og eks-premierminister Rafik Hariri Valentinsdag 14. februar 2005 kl.12.56.

Ifølge den officielle FN-version blev en lys Mitsubishi pick-up læsset med et ton sprængstof detoneret ud for Hotel Saint George-ruinen på Beiruts strandpromenade og sprængte et tre meter dybt krater i gaden, ligesom vinduer flere hundrede meter fra eksplosionen blev blæst ud.

Men de fleste er nervøse for konsekvenserne, da en opklaring, efter hvad der hidtil er sivet, indebærer, at medlemmer af Hizbollah, Guds Parti, sigtes og tiltales. Det er et problem.

Hidtil har Hizbollah været urør- lig, en stat i staten, ja sakrosant som selve 'modstanden' mod Israel. Hizbollahs guerillastyrke tilføjede Israel 'det første militære nederlag', da de israelske besættelsestropper i Sydlibanon blev trukket tilbage i foråret 2000 efter daglige tab.

I 2006 modstod Hizbollah israelernes forsøg på at eliminere partiets milits 'en gang for alle', og i dag er Hizbollah bedre bevæbnet og organiseret end nogen sinde. Partiets generalsekretær Hassan Nasrallah er et arabisk ikon, som selv sunni'er ser op til, og som ikke forsømmer nogen lejlighed til at forsikre, at han loyalt støtter Libanons religiøse og politiske pluralisme, der udmøntes i magtdeling mellem de forskellige sekter og grupperinger.

Kunne dette nationale og anti-imperialistiske parti, dette arabiske symbol på modstand mod 'den zionistiske enhed', stå bag udåden mod den arabiske leder?

\section{Hotel Saint George-symbolikken}

Gerningsstedet havde sin egen symbolik. Som en kristen taxichauffør sagde, medens han driblede sin bulede Mercedes gennem Beiruts middags-myldretid, så høstede Hariri kun som han såede - for er Saint George (Sankt Jørgen) måske ikke ondskabens banemand? Og er Hariri ikke begravet på et område, der formelt tilhører Saint George-katedralen i Beirut? Den kirke, han valgte at skænde ved at opføre en impo- 
sant moské lige ved siden af, og hvis konditor-arkitektur, alt for grønne kupler og fire minareter distraherer den visuelle oplevelse af katedralen, uanset fra hvilken vinkel man betragter den.

Nej, taxichaufføren var ikke i tvivl: "Hariri var ikke en god mand", knurrede han efter at have sikret sig, at jeg ikke citerede ham ved navn.

Men symbolikken hører ikke op ved det symbolsk religiøse: Hotellet med helgen-navnet var Beiruts absolutte society-centrum fra 1950'erne til 1975, da først en kristen milits, dernæst en muslimsk i løbet af få uger reducerede det tidligere franske officers-hotel til en udbrændt skal af rustfarvet beton.

Indtil da havde det været selve midtpunktet for de rige og de smukke, for de magtfulde og dem, der spionerede mod magten.

Hotellets bar var meldecentral for CIA, KGB og MI6, og i øvrigt det sidste sted den britiske mesterspion Kim Philby blev set i den vestlige hemisfære i 1963, før verden næste gang hørte fra ham i Moskva. Golfemirer og olie-baroner havde deres faste borde i baren, Brigitte Bardot var en velset gæst. Således symboliserede Hotel Saint George alt det, Rafik Hariri stod for 30 år senere med sit dobbelte libanesiske og saudiarabiske statsborgerskab, sin lystyacht, ferie-chalet'en i bjergene, palæet i Beiruts Konaitem-nabolag, fra limousinerne til kanonslag-cigaren og de dyre silkeslips: obskøn rigdom og politisk indflydelse.

På hat med kronprins Abdallah i Riyadh og Jacques Chirac i Paris var han legemliggørelsen af den arabiske olie-kapitalisme, han havde tjent på som entreprenør, og som nu bakkede ham op politisk. Og finansielt, da han stiftede selskabet 'Solidere', der var alle steder i Libanons finanssektor, og som renoverede Beiruts borgerkrigs-smadrede Downtown ved at købe det skud-arrede cityscape for en tredjedel af grundværdien udbetalt i aktier. Han blev premierminister i 1994 og igen i 2002 ved lige dele energi og $k ø b$ af stemmer og indflydelse - 'checkhæfte-politikeren' blev han kaldt, og som den ellers overhovedet ikke beslægtede Yassir Arafat var han ikke personligt korrupt, men korrumperede med talent og tæft sine omgivelser.

\section{Det operative forløb - indtil videre}

Om attentatmændene havde taxichaufførens fordømmelse for øje, da den dødbringende Mitsubishi med mobiltelefon-kæde blev dirigeret hen foran hotel-ruinen og parkeret i anden position, få minutter før Hariri-kortegen passerede undervejs fra parlamentet i Downtown til matadorens Konaitem-hovedkvarter, opklares næppe. Men der er en officiel version af attentatets operative forløb. Den har logiske brist, og bygger på mistænkeligt sjusket efterforskning straks efter eksplosionen, 
ligesom der synes at være begrundet tvivl om centrale vidneudsagns bonitet.

En formodning om at denne efterforskning danner grundlag for sigtelser mod Hizbollah, har forpestet atmosfæren i Libanon i hvert fald siden en fredag i juli, da Hassan Nasrallah tonede frem på tv og meddelte, at han havde vished for, at Hizbollah vil blive anklaget for mordet. I den vante rivende ordstrøm fremmanede han billedet af en plan, det særlige FN-tribunal, STL (Special Tribunal for Lebanon), havde om at tiltale navngivne Hizbollah-medlemmer i en rapport, der når dette læses måske er tilgængelig. Nasrallah var ikke til sinds at finde sig i noget sådant.

\section{Var Syrien bagmand?}

Tribunalet, bestående af 11 dommere, heraf fire fra Libanon, erstattede i 2009 den FN-efterforsknings-kommission, UN-IIIC (United Nations International Independent Investigation Comittee), der blev nedsat efter mordet i 2005, og hvis indsats mildt sagt havde været svingende.

FN's første efterforskningsleder, den tyske jurist Detlev Mehlis, der er et kontroversielt papir i sit eget land, overspillede øjensynlig sin rolle. Han fængslede summarisk de fire chefer for det hidtidige og Syrien-dirigerede libanesiske sikkerhedsapparat og sigtede dem for meddelagtighed ud fra en erklæret antagelse om, at Syrien stod bag mordet.

De fire sikkerhedschefer, alle udpeget og clearet af den syriske besættelsesmagt, bestemte reelt i Libanon op til mordet. Mehlis trådte tilbage i 2006 efter produktion af en stribe rapporter, der pegede på at Syrien stod bag mordet. Men Libanon var i krig med Israel, og libaneserne havde andet at se til.

Mehlis-rapporterne var baseret på vidneudsagn fra fem personer, der i første omgang var sendt til Libanon fra Syrien med færdigsyede forklaringer, men som blev købt af Haririlejren til at ændre forklaring.

Disse 'falske vidner' er i dag over alle bjerge, i Canada, Australien og New Zealand, men deres vidneudsagn, der stemplede syrerne og deres libanesiske medløbere som mordere, er fremdeles en meget varm kartoffel, som Hariri-lejren forsøger at feje ind under gulvtæppet. $\mathrm{Og}$ som den syrisk-støttede opposition kræver frem i lyset med henblik på at straffe de 'falske vidner' - om nødvendigt in absentia.

Syrien har udsendt 33 arrestordrer på libanesiske kabinetsmedlemmer, politikere, politifolk og jurister for at stå i ledtog med de 'falske vidner'.

\section{Efterforskning på lavt blus}

Detlev Mehlis' afløser, Serge Brammertz, en belgisk dommer, satte opklaringsarbejdet på stand by, men lod de fire sikkerhedschefer forblive 
i varetægtsarrest uden hverken tiltale eller rettergang. Brammertz hyldede princippet om, at den, der lever stille, lever godt, og da han gik af i 2008 var intet afgørende sket.

En ny FN-efterforskningsleder, canadieren Daniel Bellamare, overtog sagen, og i 2009 blev UN-IIIC-kommissionen udskiftet med det nuværende tribunal af dommere, som skal tage stilling til efterforskningens resultat, når det foreligger (hvad det muligvis gør nu, red.).

Fra 2009 kom der skub i sagerne først med en læk til det tyske magasin Der Spiegel, hvor Hizbollah første gang blev nævnt som gerningsmand. Og sidst i et dokumentar-program på Canadian Broadcast Corp. (CBC), der ligeledes udpeger Hizbollah-operative som morderne.

Angiveligt er det teleanalyser, der har knækket koderne til Hizbollahs medvirken - og det frapperende er, at analyserne var kendt $i$ hvert fald fra begyndelsen af 2007. Foretaget af en libanesisk kaptajn i den interne sikkerhedstjeneste - Wissam Eid hed han - blev de arkiveret i FN's computere, hvor de enten blev glemt eller bevidst ignoreret frem til januar 2008, hvor Bellamares efterforskningshold fandt dem ved en tilfældighed.

Krydstjek af lister over mobiltelefon-trafik er den moderne efterforsknings mest effektive sporjæger, og Wissam Eid, var som uddannet computer-analytiker i stand til at afdække fire 'telefon-netværk', der stod i indbyrdes kontakt og med snore til fastnettelefoner på 'Den Store Profet'-hospitalet i det sydlige Beirut, kontrolleret af Hizbollah.

Kaptajn Eids materiale, baseret på mobilnetværkets 'håndtryk' med sendemaster, der geografisk passede med Hariris kalender, tydede på, at han blev skygget i det meste af et år før attentatet. To navngivne medlemmer af Hizbollah var bevisligt brugere af de pågældende mobiltelefoner. En tredje person, den Hizbollah-funktionær, der samlede dem sammen efter brugen, begik en bommert, der førte efterforskningen videre. Da han så, at der var ledig tid på nogle af telefonerne, brugte han en af dem til at ringe til sin kæreste, som let blev identificeret. "Han kunne lige så godt have holdt et skilt op foran vores kontorvinduer", som en FN-efterforsker sagde.

Den operative telefonkæde, de såkaldt otte 'røde' mobiltelefoner, som efterforskerne døbte dem, der blev brugt på selve attentatdagen til at tjekke Hariri-kortegens rute, var et lukket kredsløb - der blev kun ringet imellem dem - og minuttet efter attentatet ophørte al trafik.

Men de otte i dødspatruljen havde alle parallelle telefoner, opdagede Eid, og via dem sporedes et tredje og fjerde netværk, der endte dels i Hizbollah-hospitalet, dels i det libanesiske tele-ministerium, der havde udleveret fire af mobiltelefonerne, og på listen over ministeriets 
mobilnumre havde skrevet 'Hizbollah' ud for fire numre.

Men havde gerningsmændene også en 'inside man' i Hariris stab? Måske - i hvert fald er det afdækket, at Hariris personlige sikkerhedschef, Wissam al-Hassan, har løjet om sit alibi på morddagen. Han fortalte FN-efterforskerne, at han var kaldt til en eksamen på det Beirut-universitet, hvor han studerede til en ph.d. - han havde læst lektier hele den formiddag og havde slukket sin mobiltelefon, da han ankom til eksamensbordet næsten samtidig med, at attentatet fandt sted. Men via telefonlisterne fandt FN-folkene ud af, at han havde 'tilkaldt' sig selv med en opringning til den eksaminerende professor - i øvrigt er det usædvanligt, at libanesere i højtstående positioner går til eksamen.

Han forklarede, at han havde bedt sig fri hos Hariri med den begrundelse, at han var blevet 'tilkaldt', men telefonlisterne viser, at han talte med Hariri en halv time før, han ringede til professoren og 'tilkaldte' sig selv. Efterforskerne ville tjekke med professoren om 'tilkaldelsen', men fik forbud mod at henvende sig af efterforskningsleder Serge Lammertz, der frygtede, at det ville skabe politisk støj. I dag er Wissam al-Hassan chef for det libanesiske politis efterretningstjeneste, og har - uanset afsløringen af hans vaklende alibi - fortsat Saad Hariris 'fulde tillid'.

Hizbollahs parlamentarikere og ministeren for kommunikation har i takt med de pinagtige læk beskyldt Israel for at have 'hacket' de libanesiske tele-computere og 'manipuleret' opkaldslister og 'plantet' telefonnumre for at lede efterforskerne på vildspor. Deres teori, bakket op af nogle journalister og tekniske eksperter, er, at israelerne manipulerede telefonlisterne via computerhacking, at israelske droner havde kortlagt Hariri rute på morddagen, at bomben ikke var en pakket lastbil, men et tysk fremstillet missil afskudt fra en drone i luften - krateret kunne ikke blive så dybt med en overfladeeksplosion, siger teknikere - og at Hariris israelsk fremstillede 'bombe-radar' i hans limousine var jammet kort før eksplosionen.

Denne teori - fremført af Hizbollah og andre - forudsætter, at israelerne ville kreere 'et sunni-offer', dels for at opvigle sunni'er mod shia'er, dels for at sværte Hizbollah internationalt. "Hizbollah kunne ikke besejres militært, men kan måske elimineres propagandamæssigt", som en af mine libanesiske kolleger anførte.

\section{Hvem havde interessen?}

Det er en mulighed - men er den sandsynlig? Havde Israel en interesse i at myrde Rafik Hariri? De fleste mener nej-derimod er det kendt, at Hariri fra 2004 kom på kollissionskurs med syrerne, der krævede at hans politiske parlamentsblok 
stemte for forlængelse af den Syrienvenlige præsident, Emile Lahoud, i yderligere tre år.

Hariri, der afskyede Lahoud, bøjede sig modvilligt, men havde også kontakt til Frankrig og USA i forbindelse med vedtagelsen af FN-resolution 1559 fra 2004, der kræver afvæbning af Hizbollah og syrisk tilbagetrækning fra Libanon. "Han blev myrdet, fordi han lå i med Chirac og Bush", sagde en 8. Marts-journalist, da vi drøftede forløbet.

Og i hvert fald er det sådan, at fra 2005 til begyndelsen af 2009 var Syrien og dets libanesiske medløbere hovedmistænkte for Hariri-mordet de havde et motiv, de havde tradition for at ordne politiske uenigheder med bomber, og de var nervøse ved en mulig amerikansk beslutning om et 'regimeskifte' i Damaskus, hvilket rent faktisk blev overvejet i Bush-administrationen.

Men efter 2009 blev Syrien slettet fra listen af mistænkte. Det var påfaldende, at Der Spiegels artikel, formentlig baseret på en læk i FN og muligvis i den (nu anti-syriske og vest-orienterede) libanesiske sikkerhedstjeneste, hængte Hizbollah ud som skyldig, men rensede syrerne. Især i betragtning af, at al logik pegede på syrisk medviden. Alene attentatets voldsomhed kunne umuligt planlægges og udføres, uden at de syriske og libanesiske sikkerhedstjenester vidste om det. Tilvejebringelse og transport af et ton sprængstof kunne ikke - siger logikken - finde sted uden at være clearet. Artiklen faldt sammen med den begyndende vestlige rehabilitering af det syriske diktatur.

Ligeledes virker det påfaldende, at FN's udskiftning af efterforsknings-kommissionen med et nyt tribunal i 2009 kom, efter at USA og Frankrig var begyndt at bearbejde præsident Bashar al-Asssads styre til at droppe den militære alliance med Iran, udmøntet i bl.a. syriske transportruter for iranske våbenleverancer til Hizbollah. Som den første embedshandling løslod det ny tribunal de fire syrisk-venlige libanesiske sikkerhedschefer efter næsten fire år varetægt.

Endelig forekommer det påfaldende, at de to hovedvidner til syrisk meddelagtighed, som Detlev Mehlis havde forudsat, nemlig Bashar al-Assads toprådgiver og forbindelsesofficer til Hizbollah, general Mohamad Suleiman, og Hizbollahs militære chef, Imad Mughniyeh, begge blev likviderede i 2008 - og begge i Syrien.

Hvis det syriske styre var vidende om eller ligefrem involveret i mordet, ville disse to være de nærmeste til at vide det. Med de to snigmord var eventuel forbindelse til Bashar og hans inderkreds elimineret, og Syriens dementier af kendskab til attentatet kunne tages til efterretning af Vesten. Og efterlod Hizbollah som det bekvemme og isolerede mål for mistanke. Døden skulle trods alt have en årsag. Den årsag er ifølge 
Nasrallahs talrige offentlige erklæringer og taler israelsk.

Og, lagde Nasrallah til, at der er tale om 'et israelsk komplot', bevistes med optagelser fra israelske droner, der havde filmet gerningsstedet. I sig selv er de ikke noget bevis, men i Nasrallahs optik var hensigten med mordet at skabe mistro til Hizbollah og dets rolle i modstandskampen mod Israel. Hvorfor det ifølge Nasrallah er udelukket, at libanesiske myndigheder, der deltager i tribunalet og bidrager til dets finansiering, fortsat kan have tiltro til dette tribunal. Han kræver, at Saad Hariri tager afstand fra tribunalet endnu inden en endelig rapport er offentliggjort - simpelt hen af hensyn til de 'helt uforudsigelige konsekvenser', der ellers vil være mulige.

"Hizbollah, det er mig", som Nasrallah sagde, "og vi skærer hånden af enhver, der forsøger at anholde vores medlemmer". Nasrallah afviser altså at acceptere tribunalet, hvilket indebærer, at han også udelukker, at Libanons myndigheder, med fire dommere i tribunalet og bidrag til dets udgifter, reagerer på eventuelle anklager. Nasrallah forlanger, at Saad Hariri og hans '14. Marts'-bevægelse på forhånd afviser eventuelle sigtelser og tiltaler. Saad Hariri har på sin side trådt vande, vel vidende at dersom han ikke makker ret, er en ny borgerkrig lige om hjørnet - "og han selv i eksil på Cypern”, som en politisk redaktør udtrykte det.

\section{Bekymringens teater}

Måske skal man bo i Libanon for at fatte rækkevidden af den nervøsitet, libaneserne har gennemlevet i sidste halvdel af 2010. Udadtil mærkes der ikke meget til den ud over i de daglige aviser og nyhedsudsendelser livet i Beirut går videre i støjende og dyttende mangfoldighed, nu og da peppet op med fyrværkeri og israelske overlydsfly, der dykker ved Cornischen og skræmmer joggere og familier, der promenerer med ungerne eller har slået sig ned med havudsigt til aften-vandpiben.

Men lytter man sig ind på samtalerne, handler de om udsigten til borgerkrig. Og håbet om et mirakel, der kan sikre en fredelig udgang på tribunalets formodede anklageskrift.

Et sådan mirakel arbejdes der på - både i Libanon, og især udenfor. For medens jeg sidder i den stadig lune novemberaften på min altan $\mathrm{i}$ Hamra-kvarteret og taster ord ind på labtop-skærmen, forhandles der i Riyadh og Damaskus, i Ankara og Teheran, i Bagdad, New York, Paris, Washington - og Jerusalem.

Alle har de aktier i det lille land med godt fire mio. indbyggere og ikke større end Fyn og Sjælland. Et land opdelt i 17 sekter, der igen er delt i to politiske hovedgrupperinger, '14. Marts', støttet af USA-Vesten, og '8. Marts', støttet af SyrienIrak.

Saad Hariris sunni-bevægelse og et antal kristne falangist-partier ud- 
gør '14. Marts', indtil 2009 sammen med Walid Jumblatts drusere - som har meldt sig ud. ' 8 . Marts' består af shia-partierne Hizbollah og Amal, nogle mindre syrisk-nationalistiske grupper og Michel Aoun, den kristne eks-general og kortvarigt selvudnævnte præsident i 1990, det sidste borgerkrigsår.

At Aoun er med i 'oppositionen' som leder af det største kristne parti - og som tidligere indædt modstander af Syrien - skyldes dels, at han stadig nurser et håb om, at shia'erne vil gøre ham til præsident, dels en kølig kalkulation af de kristnes fremtid i et shia-domineret Libanon. Allerede nu udgør shia'erne ca. 40 pct. af befolkningen, og er groft underrepræsenteret i forfatningen (de er parlamentsformænd, sunni'erne er altid premierministre og præsidenten er altid kristen).

Denne underrepræsentation i regering og parlament er en del af forklaringen på, at Hizbollah insisterer på at bevare en væbnet milits (bedre udrustet end den libanesiske hær), som en krænkelse af FN-resolutionerne 1559 og 1701. Shia'ernes manglende nominelle politiske indflydelse opvejes altså af et våbenarse- nal, hvis størrelsesorden også virker afskrækkende (nogle mener udfordrende) på Israel.

\section{Diplomatisk cirkus}

Det seneste halve år har politikere og diplomater brugt formuer på flybilletter ind og ud af Beirut for at tale sagen ned på et håndterligt niveau. Og medens dette skrives hælder de nervøse deres hoveder og forhåbninger til forhandlinger mellem Syrien og Saudi-Arabien (med Iran på sidelinjen som Hizbollahs sponsor) om en blød landing.

Lykkes det ikke at få landingshjulene ud, kan det ende blodigt. Hizbollah-medlem af parlamentet Walid Sukarriyeh er enig i min kollega Ernests indledende ord, men med en rygrads-rislende tilføjelse: "Og hvad så, hvis Hizbollah slog Hariri ihjel?" sagde han til avisen $A n$ Nahar, "ingen har interesse i at smadre Libanon."

Vi får se.

Lasse Ellegaard er journalist; korrespondent i Mellemøsten for Dagbladet Information med bopal $i$ Beirut. 